\title{
Ecotoxicological evaluation of arsenic in soils based on wheat test
}

\author{
Nataliia Makarenko, \\ Valeria Bondar \\ National University of Life \\ and Environmental \\ Sciences of Ukraine, \\ Heroiv Oborony St, 15, \\ Kiev, 03041, Ukraine \\ E-maillera_bond@email.ua
}

\begin{abstract}
The results of the "dose-effect" correlation research are represented by measuring changes in a biota. The possibility to use the "crucial center" in the ecotoxicological standardization of the chemicals influence on the ecosystems is shown. The usage of the soil condition microbiological indicators and biological tests is supposed to be rational in the assessment of the arsenic negative impact on the ecosystem. According to the reaction of the most sensitive biological tests (active processes of nitrification, germination of garden cress, red radish with a white tip), regarding arsenic, it has been experimentally established that the concentration exceeding $5 \mathrm{mg} \mathrm{As} / \mathrm{kg}$ is dangerous for the groundwater system.
\end{abstract}

Key words: arsenic, biological tests, ecotoxicological standardization, soil

\section{INTRODUCTION}

The soil degradation including the chemical one is a crucial current problem. The soils change their physical, chemical and biological properties influenced by chemical pollutants (Kabata-Pendias, 2001). The prevention of these negative phenomena requires the development of the ecotoxicological standard systems thanks to which it is possible to fulfill the preventive chemical hazard assessment in the agroecosystem components. The methodological basis for the development of ecotoxicological standards can be the empirical curve "dose-effect" construction by measuring changes in biota under the influence of chemical substances. The changes studying is advisable to be carried out through the "crucial center" - the group of species, or the only species, the tolerance range of which regulates the exposure levels of chemical substances. It is thought (Kabata-Pendias, 2001) that even the changes in one species outside its optimum zone can lead to stress of the whole ecosystem.

In order to provide the assessment of the negative impact of different substances on the soil the modern level of research involves the extensive application of bioassay methods, the use of appropriate organism reactions to the impact of envi- ronmental factors (Kabata-Pendias, 2001). This approach of the soil environmental condition is based on the fact that the implementation of the processes that occur in the body are caused both by the organism specifics and by the environment itself. Above all, the organism depends on the environment because of the nature of its resources and the factors that influence the metabolism. Besides, the state of the environment can be judged from the number or the growth intensity of different species, from the populations and the entire groups of certain organisms. More sensitive to the effects of the environmental factors are the species with a low tolerance degree. They are called stenobionts, the organisms with a narrow range of life opportunities, especially at the change of certain environmental factors, including an anthropogenic one (Sherene, 2010). Not only the lack of some chemicals could be the limiting factor but also their excess. So the environmental viability of organisms is characterized by the ecological minimum and maximum and the range of these values is the environmental tolerance limit. The majority of the biological species are adapted not to a certain value of the given factors, but to the limits of their variability in nature and the extent of their temporal fluctuations (Cechmankova et al., 2010). 
The basis of the environmental testing is formed by the organism reaction on the impact of environmental factors (Kabata-Pendias, 2001). The organism is capable of surviving only in the range of variability of the given factor which is also called the amplitude. Both an extremely high (maximum) and extremely low (minimal) influence of the environmental factors can have the detrimental effect on the organism. The threshold of the given factor, expressed quantitatively, above or below which the body cannot exist, is called a critical point. Between these critical values, there is a zone of ecological tolerance. The intensity of the environmental factors is different within the zone of the environmental tolerance. Near the critical points, there are the pessimal zones, where the activity of the organism is greatly limited by the external conditions. Then there are the comfort zones, in which there is a significant increase of the organism environmental reactions. There is also the optimum zone in the center, which is the most favorable zone for the functioning of the organism.

Recent research has shown (Kabata-Pendias, 2001; Bolan et al., 2008) the possible negative reaction of organisms on the both insufficient and excessive quantity of chemical elements in the soil. This excessive amount of chemical elements is the toxicants, and they become the subject of an ecotoxicological study.

In order to perform the bioassay of the chemicals in the soil system, it is necessary to select the indicators of the biota, which are characterized by the lowest optimum and comfort zones. The comparison of the amplitudes of variability factors in which the biota reaction passes from the optimum zone to the comfort zone and further to the pesymum zone gives the possibility to separate out those indicators of the biota which are the most sensitive. The level of the deviation from the standard reaction of the organism (control) might show the potential negative impacts of a particular chemical on the soil system. While conducting the ecotoxicological assessment, it is accepted that the deviation of less than $10 \%$ is a low dangerous level, $10-25 \%$ deviation is moderately dangerous and more than 25\% deviation is dangerous (Makarenko, Bondar, 2013). If to take it as a base, the reaction of organisms on the chemical can be estimated as follows: optimum zone decrease $<10 \%$, comfort zone decrease $10-25 \%$, pesymum decrease $>25 \%$.
The priority attention should be given to the chemicals of hazard class 1 which are highly dangerous. These substances include arsenic and its compounds. As it was stated previously in the literature review, arsenic is the fourth element of the fifth group in the periodic table of elements (Jigau et al., 2014). It exists in two chemical forms: bivalent and three-valent. Three-valent arsenic is more toxic and refers to the carcinogenic substances. The toxic effect of As is associated with its ability to form stable compounds with the thiol groups of enzymes, to damage the central nervous system, and to lead to the paralysis of the capillaries. At present, the data on the toxic effects of arsenic on superior plants, microorganisms and mesofauna are fragmented and not systematic. Sanitary and hygienic requirements for arsenic in the soil are not coordinated with its actual content in different soils of Ukraine. The maximum concentration of As is $2 \mathrm{mg} / \mathrm{kg}$, the background concentration in soils varies from 0.5 to $10 \mathrm{mg} / \mathrm{kg}$. This makes it difficult to assess the danger of the element in components in all the agro-ecosystems and makes it essential to conduct the research towards the definition of the permissible As concentrations in soil.

\section{MATERIALS AND METHODS}

In the research all the system of indicators for the bioassay was used at the molecular (biological processes), ontogenetic (organism tolerance at certain stages of ontogeny), biogeocoenotic (changes in the number of certain types of organisms in soil systems) and at other levels of life organization. The purpose of the research was to determine the "critical" species of biota or to distinguish the activity of physiological, biochemical processes which are important indicators of the threatening concentration of arsenic in the soil. An artificial soil contamination has been created just for the research. Arsenic has been brought in the form of an aqueous solution of $\mathrm{As}_{2} \mathrm{O}_{3}$ according to the following scheme: control (0), 5, 10, 25, 50, 75, 100, 125, $150,175 \mathrm{mg} / \mathrm{kg}$ of soil.

Soil enzymatic activity has been determined by Galastian's method; nitrification activity has been determined by Kravkov's method; arsenic toxicity to the sprouting crops has been determined by Grodzinskiy's method; arsenic toxicity to the soil mesofauna representatives has been studied on 
the indicator species Eisenia foetida (earthworms). The authenticity and reliability of research results are confirmed by the mathematical statistics data using the sample variance, regression, correlation analyses.

\section{RESULTS AND DISCUSSION}

It is supposed that the indicators of soil "enzymatic mirror" are sensitive to the exogenous chemicals. These indicators are the set of enzymatic reactions, which are indicators of the intensity of biochemical processes in the soil (Hashimoto et al., 2009). The combination of enzymatic reactions, which are being studied, is not strictly obligatory in all cases. It can vary depending on the nature of the chemical. The enzyme activity of different groups is correlatively linked, so it is possible to define the activity of one enzyme or just a representative from each group. In our research we have chosen to study the enzymes of the oxidoreductases group - polyphenol oxidases and peroxidases. According to recent research, the activity of these enzymes can give us information about the general direction intensity of the processes in the soil because oxidoreductases are involved in the synthesis and mineralization of humus.

The laboratory studies of the redox enzymes reaction on the artificial soil contamination with arsenic concentrations from 5 to $175 \mathrm{mg} / \mathrm{kg} \mathrm{As} \mathrm{O}_{3}$ have shown that As is actively involved in the oxidationreduction process of the soil organic matter, and the most mobile components of humus substances with the help of polyphenol oxidases attach atomic oxygen and turn into the compounds such as oxygenase. Oxygenases involving peroxidase transmit the absorbed oxygen from the air to plants and are transformed into the compounds such as quinones. At the same time, as we know, quinones absorb the excessive hydrogen generated in the cells and then are transformed into the humic substances. It has been found that the toxic effects of arsenic are evident only in respect to the enzyme polyphenol oxidase and at very high concentrations of As in soil - at the level of $175 \mathrm{mg} / \mathrm{kg}$. Peroxidase enzyme activity in artificial pollution has slightly decreased compared to the control, but only to a certain level - with the increasing concentrations of As from 5 to $50 \mathrm{mg} / \mathrm{kg}$ (plus 7\%). With the following increasing concentrations of As to $175 \mathrm{mg} / \mathrm{kg}$ peroxidase enzyme activity increased as well, and this indicates the growing oxidation processes in the soil organic matter under the influence of arsenic. The obtained data have shown that despite the high sensitivity of oxidoreductase enzymes to soil contamination of arsenic this indicator is inappropriate for using as the norm of environmental standardization of As because there has been no linear relationship between the pollution levels and the activity of enzymes.

In addition to the enzymes activity, there is a measure of the ability of soil nitrification, which is also sensitive to chemicals contamination. The researches of the Institute of Experimental Biology and Ecology of the Slovak Republic have shown that thanks to high nitrificant standards of the environmental conditions nitrification is possible to be considered as the objective and sensitive indicator of soil systems.

In our research, the nitrification activity in the creation of artificial backgrounds of arsenic soil contamination has decreased by $18-46 \%$ compared with the control. Arsenic concentrations in soil from 5 to $10 \mathrm{mg} / \mathrm{kg}$ have led to the nitrification activity decrease by $18-21 \%$ compared with the control. Such deviations from the norm correspond to the moderately dangerous level of pollution. At the increase of the arsenic concentration in the soil to $25 \mathrm{mg} / \mathrm{kg}$ nitrification, the activity decrease has reached the level of $26 \%$, which corresponds to the pesymum zone and dangerous level of pollution. Higher concentrations of arsenic in the soil to $50-175 \mathrm{mg} / \mathrm{kg}$ has led to the following nitrification activity decrease to $39-46 \%$ compared with that of the control, which corresponds to the dangerous level of pollution. The relationship between the concentrations of arsenic in soil and the level of its nitrification activity is described by the equation $y=0.1466 x^{2}-2.5889 x+24.005$ with a high correlation $\left(\mathrm{R}^{2}=0.943\right)$ (Fig. 1).

The research has shown that for the environmental standardization of arsenic it is advisable to use a nitrification ability as an indicator of soil.

Along with the nitrification activity and putrefaction of microorganisms, the ecotoxicological studies widely use the reactions of mesofauna representatives, particularly earthworms. Currently, all laboratories around the world are using the species such as Eisenia andrea, Lumbricus terestris, Aporrectodea caliginosa, Aporrectodea chlorotica, 


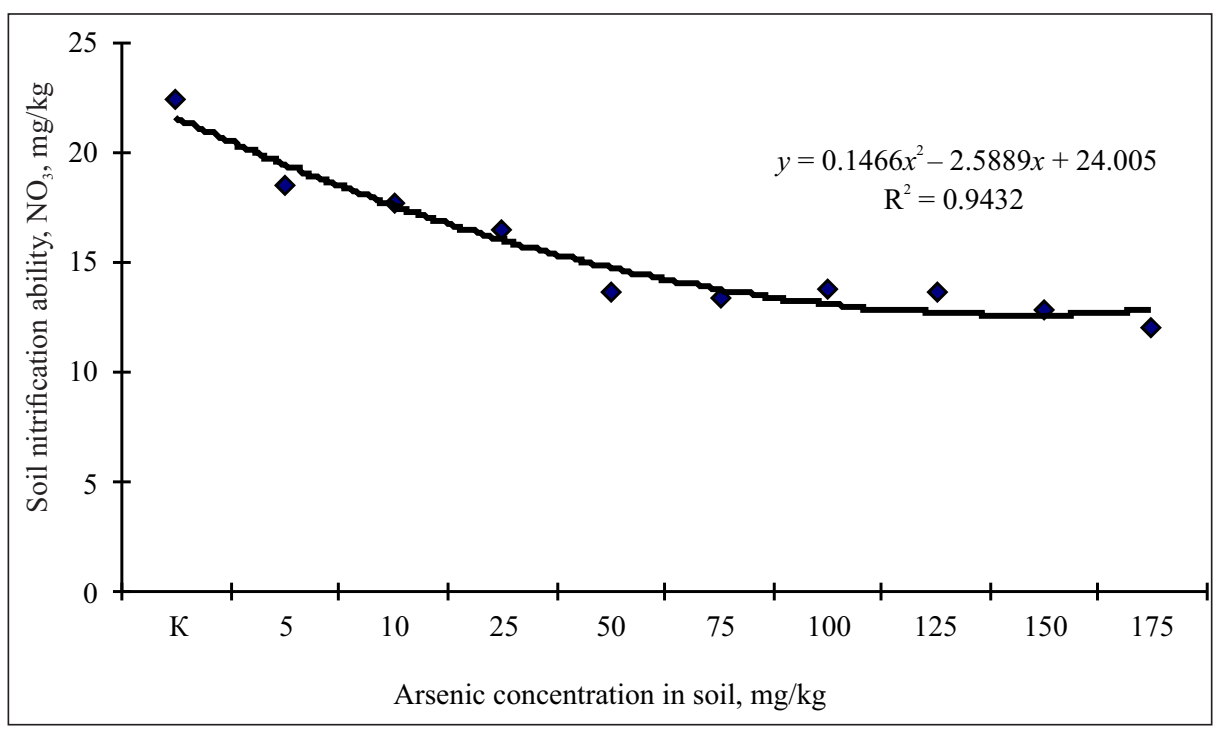

Fig. 1. The influence of artificial arsenic contamination of gray forest soil on its nitrification ability

Aporrectodea nocturna, worms Eisenia foetida are also recommended as a standard laboratory kind to assess toxicity (Mukherjee et al., 2006).

The research has been conducted together with the Department of Zoology KSU named after T. H. Shevchenko. In vitro the reactions of the earthworm species Eisenia foetida to arsenic soil contamination at the concentrations of $0,5,10,25$, $50,75,100,125,150,175 \mathrm{mg} / \mathrm{kg}$ have been studied. In order to determine the acute toxicity of arsenic the earthworms were detained in artificial soil for 14 days (sand, clay, peat moss, $\mathrm{CaCO}_{3}$ ). The criterion of toxic action has been the mortality of the test objects. During the experiment the monitoring of the general state of animals, their mobility, the response to stimuli has been conducted. The worms have been considered dead if they did not respond to the mild mechanical irritation of the frontal end of the body. The results of the study have shown that at the arsenic concentrations in soil from 5 to $150 \mathrm{mg} / \mathrm{kg}$ the mortality rate was $2.5 \%$ compared with the control. Higher concentrations of arsenic in the soil to $175 \mathrm{mg} / \mathrm{kg}$ have led to the mortality rate increase to $5 \%$ compared with that of the control. Therefore, the reducing number of the test organisms in the experiment has not exceeded 10\% compared with that of the control which corresponds to the dangerous level of pollution.

However, it should be noted that all the experimental earthworms died in the following 20 days after the end of the experiment indicating the chronic toxicity even of the low concentrations of arsenic, and it needs additional research.

A common type of bioassay is phyto testing which is the determination of the environmental conditions by the state of the plant. Phyto testing uses a wide range of the test-plants, among which the most significant are cereals, pulses, haze, etc. It is advisable to study the reaction of the plants on arsenic soil contamination at different stages of ontogeny.

The research has been conducted in vitro in order to investigate the characteristics of arsenic revenue into the plant of spring wheat (cultivar Early Rannia 93), which was grown on the gray forest soil. In the soil the arsenic concentration was in the range from 5 to $175 \mathrm{mg} / \mathrm{kg}$. The results of biometric studies have shown that in the early stages of development (stairs phase, 3-leaf emergence, tillering) not high concentration of As (5-25 mg/kg) has shown some stimulating effect and there has been a tendency to increase the height of wheat plants. Arsenic concentration with more than $50 \mathrm{mg} / \mathrm{kg}$ has a negative influence on plants. In the later phases of the wheat development (stem development) a clear correlation between the plant height or root length, and the level of soil contamination has not been observed (Table 1).

Unlike the biometric research, the chemical analysis of the arsenic content of wheat plants has shown a clear correlation between the concentration of As in the root system, overground 
vegetative mass and element content in the soil. It has been proved that arsenic moved more actively to the plant roots, with increasing levels of soil contamination by arsenic from 5 to $175 \mathrm{mg} / \mathrm{kg}$, the concentration of the element in the root system has increased by 2.5-10.5 times compared with that of the control. A clear correlation has been observed between soil and the concentration of arsenic in the root system of wheat described by $y=0.0517 x^{2}+0.0455 x+0.1142$ with a high correlation level $\left(R^{2}=0.955\right)$. The revenues of arsenic in the aboveground vegetative mass of the plants have been less active, due to the protective function of the root system, which is a biological filter against the toxic elements (Fig. 2).

A more detailed study of these processes has been determined by the method described by
A. Grodzynskii on wheat seedlings. The results have shown that the arsenic concentration till $25 \mathrm{mg} / \mathrm{kg}$ might slightly stimulate the development of the embryonic root (its length increased by $6.0-3.3 \%$ compared with that of the control), but there has been a negative impact on the shoots grain development even at such low concentrations of the element (the length of shoots has decreased by $11.2-16.7 \%$ compared with that of the control). The increased concentrations of arsenic to $100 \mathrm{mg} / \mathrm{kg}$ and more have led to the inhibition of embryonic development of roots and shoots, their length decreased compared with that of the control by $40-50 \%$ and $38.9-88.9 \%$, respectively. Such level of arsenic soil contamination on the indicators development of the test objects can be considered dangerous (Table 2).

Table 1 . The influence of arsenic on plant height and root length of spring wheat $(\mathrm{cm})$

\begin{tabular}{c|c|c|c|cc}
\hline \multirow{2}{*}{$\begin{array}{c}\text { The arsenic } \\
\text { concentration in } \\
\text { the soil, } \mathbf{~ m g} / \mathbf{k g}\end{array}$} & \multicolumn{5}{|c}{ Wheat development phase } \\
\cline { 2 - 6 } & Stairs phase & 3-leaf emergence & Tillering & Access to the tube leaves + stem root \\
\hline Control & $2.62 \pm 0.10$ & $8.00 \pm 2.23$ & $21.70 \pm 3.97$ & $26.90 \pm 3.20$ & $3.60 \pm 0.06$ \\
\hline 5 & $3.20 \pm 0.30$ & $8.80 \pm 2.58$ & $22.80 \pm 6.45$ & $29.00 \pm 2.59$ & $4.30 \pm 0.05$ \\
\hline 10 & $3.40 \pm 0.20$ & $10.80 \pm 0.14$ & $23.40 \pm 2.21$ & $27.30 \pm 2.82$ & $3.90 \pm 0.05$ \\
\hline 25 & $3.83 \pm 1.00$ & $10.40 \pm 1.22$ & $23.20 \pm 3.37$ & $25.80 \pm 2.39$ & $3.70 \pm 0.07$ \\
\hline 50 & $1.50 \pm 0.06$ & $10.90 \pm 0.76$ & $21.10 \pm 0.87$ & $25.40 \pm 1.74$ & $3.60 \pm 0.06$ \\
\hline 75 & $1.13 \pm 0.05$ & $7.60 \pm 0.57$ & $18.80 \pm 2.65$ & $24.80 \pm 0.80$ & $3.30 \pm 0.12$ \\
\hline 100 & $1.30 \pm 0.07$ & $9.60 \pm 1.88$ & $19.80 \pm 2.17$ & $26.70 \pm 4.37$ & $3.80 \pm 0.38$ \\
\hline 125 & $1.20 \pm 0.04$ & $8.40 \pm 1.03$ & $18.90 \pm 1.86$ & $27.40 \pm 1.65$ & $3.80 \pm 0.19$ \\
\hline 150 & $1.40 \pm 0.09$ & $7.80 \pm 0.62$ & $18.60 \pm 0.14$ & $25.60 \pm 3.36$ & $3.40 \pm 0.14$ \\
\hline 175 & $1.20 \pm 0.02$ & $9.60 \pm 3.31$ & $17.7 \pm 2.73$ & $27.20 \pm 0.66$ & $3.50 \pm 0.50$ \\
\hline$L_{5} 5$ & 0.13 & 0.88 & 0.32 & 0.55 & 0.16 \\
\hline
\end{tabular}

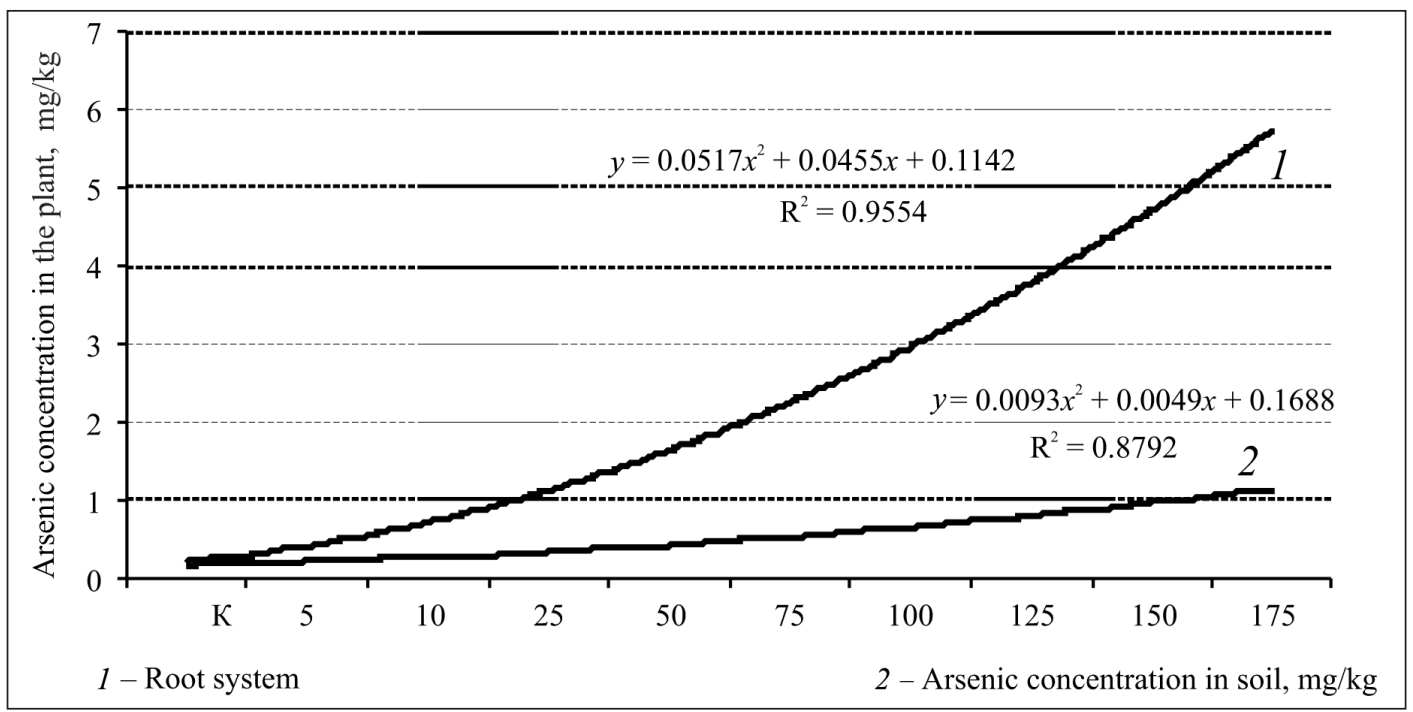

Fig. 2. Arsenic accumulation by spring wheat in artificial soil contamination 
Table 2. Indicators of wheat grain development in artificial arsenic soil contamination

\begin{tabular}{|c|c|c|c|c|}
\hline \multirow[b]{2}{*}{$\begin{array}{c}\text { Arsenic } \\
\text { concentration, } \\
\mathrm{mg} / \mathrm{kg}\end{array}$} & \multicolumn{4}{|c|}{$\begin{array}{c}\text { Biometric parameters of } \\
\text { wheat grains }\end{array}$} \\
\hline & 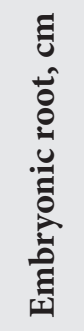 & 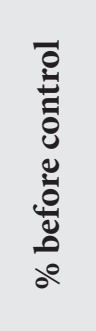 & $\begin{array}{l}\text { हี } \\
\hat{\Xi} \\
\text { ڤँ } \\
\text { के }\end{array}$ & 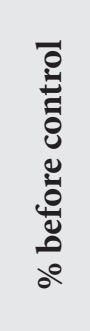 \\
\hline Control (0) & 3.0 & - & 1.8 & - \\
\hline 5 & 3.2 & 6.6 & 1.6 & -11.2 \\
\hline 10 & 3.1 & 3.3 & 1.6 & -11.2 \\
\hline 25 & 3.1 & 3.3 & 1.5 & -16.7 \\
\hline 50 & 2.8 & -6.7 & 1.5 & -16.7 \\
\hline 75 & 2.7 & -10.0 & 1.5 & -16.7 \\
\hline 100 & 1.8 & -40.0 & 1.1 & -38.9 \\
\hline 125 & 1.8 & -40.0 & 1.1 & -38.9 \\
\hline 150 & 1.7 & -43.4 & 0.4 & -77.8 \\
\hline 175 & 1.5 & -50.0 & 0.2 & -88.9 \\
\hline $\mathrm{LSD}_{5 \%}$ & 0.03 & - & 0.02 & - \\
\hline
\end{tabular}

It is commonly believed that among the phyto indicators of the plant for soil contamination by toxic substances high sensitivity is shown by red radishes with a white tip (Raphanus sativus L.) and garden cress (Lepidium sativum L.) (Mukherjee et al., 2006).

The laboratory studies conducted with the mentioned plants have shown that they can be successfully used for the environmental standardization of arsenic soil contamination. Even in the creation of contamination at the level of $5 \mathrm{mg} / \mathrm{kg} 14 \%$ in germination of red radish was observed and $4 \%$ decrease of garden cress compared with that of the control. With an increase of As contamination to a level of $10 \mathrm{mg} / \mathrm{kg}$ germination of red radish has decreased by $27 \%$, which indicates the creating of a pesymum zone for plants. The contamination of soil at the level of $10 \mathrm{mg} / \mathrm{kg}$ may be evaluated as dangerous. The arsenic contamination of soil by more than $25 \mathrm{mg} / \mathrm{kg}$ has resulted in a significant inhibition of germination both of red radish and garden cress. and at arsenic concentrations of $150-175 \mathrm{mg} / \mathrm{kg}$ there has been the total loss of plant (Table 3).

In respect to the general high sensitivity of red radish and garden cress to As contamination, some differences in the response of the plant to the increasing concentrations should be noted. Red rad-
Table 3. Reaction of phyto indicator plants on the arsenic contamination

\begin{tabular}{|c|c|c|}
\hline \multirow{2}{*}{$\begin{array}{c}\text { Arsenic concen- } \\
\text { tration in soil, } \\
\text { mg/kg }\end{array}$} & \multicolumn{2}{|c|}{$\begin{array}{c}\text { Similarity, \% as compared to } \\
\text { that of the control }\end{array}$} \\
\hline & $\begin{array}{l}\text { Red radish } \\
\text { (Raphanus } \\
\text { sativus } \mathrm{L} . \text { ) }\end{array}$ & $\begin{array}{l}\text { Garden cress } \\
\text { (Lepidium } \\
\text { sativum L.) }\end{array}$ \\
\hline Control & 100 & 100 \\
\hline 5 & 86 & 96 \\
\hline 10 & 73 & 86 \\
\hline 25 & 73 & 72 \\
\hline 50 & 61 & 38 \\
\hline 75 & 42 & 23 \\
\hline 100 & 17 & 8 \\
\hline 125 & 13 & 7 \\
\hline 150 & 4 & Total loss \\
\hline 175 & Total loss & Total loss \\
\hline $\mathrm{LSD}_{5 \%}$ & 7.76 & 8.16 \\
\hline
\end{tabular}

ish has shown greater sensitivity to low concentrations of the element - within 5-25 mg/kg, and there has not been the acute response of the plant with its further increase. Garden cress, on the contrary, has shown greater sensitivity at arsenic concentrations of $50 \mathrm{mg} / \mathrm{kg}$ and more. Such peculiarities of the phyto indicator plants may be associated with the different nature of their resistance to the contamination - resistant and resilient. The described peculiarity should be used in evaluating different levels of arsenic soil contamination caused by industrial accidents. The generalization of the obtained material has provided an opportunity to identify the most sensitive tests of soil contamination by arsenic and to establish the levels of contamination that may adversely affect the biological objects of agro-ecosystems. This presumed that the dangerous levels of pollution must be considered as those in which biological objects come to the transition from the comfort conditions to the pesymum - decrease in the activity of biochemical, physiological processes makes $10-25 \%$ and more compared with that of the control. Such level of arsenic soil contamination can be considered moderately dangerous and dangerous. Based on this approach, the most sensitive tests have been determined - nitrification ability of soil reaction and phyto indicators - red radish with a white tip and garden cress. According to these reaction tests, the threatening level for the ecosystems can be the arsenic concentration in the soil above $5 \mathrm{mg} / \mathrm{kg}$ (Table 4 ). 
Table 4. Arsenic concentration in soil, in which biological objects come to the transition from the comfort conditions to the pesymum

\begin{tabular}{|c|c|c|c|c|c|c|c|}
\hline \multirow{3}{*}{$\begin{array}{l}\text { Arsenic con- } \\
\text { centration in } \\
\text { soil, } \mathrm{mg} / \mathrm{kg}\end{array}$} & \multicolumn{7}{|c|}{ Bioindicators } \\
\hline & \multirow{2}{*}{$\begin{array}{l}\text { Nitrifi- } \\
\text { cation } \\
\text { ability of } \\
\text { soil }\end{array}$} & \multirow{2}{*}{$\begin{array}{l}\text { Enzymatic } \\
\text { activity of soil, } \\
\text { polyphenol } \\
\text { oxidase }\end{array}$} & \multirow{2}{*}{$\begin{array}{l}\text { Earth- } \\
\text { worms } \\
\text { Eisenia } \\
\text { foetida }\end{array}$} & \multirow{2}{*}{$\begin{array}{l}\text { Red radishes } \\
\text { with a white } \\
\text { tip (Raphanus } \\
\text { sativus L.) }\end{array}$} & \multirow{2}{*}{$\begin{array}{l}\text { Garden } \\
\text { cress } \\
\text { (Lepidium } \\
\text { sativum L.) }\end{array}$} & \multicolumn{2}{|c|}{ Wheat grains } \\
\hline & & & & & & $\begin{array}{c}\text { Embryonic } \\
\text { root }\end{array}$ & Sprout \\
\hline \multicolumn{8}{|l|}{ Control (0) } \\
\hline \multicolumn{8}{|l|}{5} \\
\hline \multicolumn{8}{|l|}{10} \\
\hline \multicolumn{8}{|l|}{25} \\
\hline \multicolumn{8}{|l|}{50} \\
\hline \multicolumn{8}{|l|}{75} \\
\hline \multicolumn{8}{|l|}{100} \\
\hline \multicolumn{8}{|l|}{125} \\
\hline 150 & & & & & Total loss & & \\
\hline 175 & & 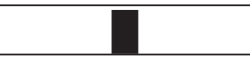 & & Total loss & Total loss & & \\
\hline
\end{tabular}

\section{CONCLUSIONS}

Arsenic is an element of mixed valence, is in the periodic system on the verge between metalnon-metal, possesses properties typical for both metals and for non-metals; moreover, the processes, accompanied by changes in its valence are very characteristic. Chemical properties of arsenic determine features of its behavior in the natural environment, particularly in soil. which in its turn affects the processes of migration and translocation, bioavailability and toxicity.

The influence of the ecotoxicological standardization of the chemicals on the ecosystems can be studied according to the results of the "dose-effect" correlation by measuring changes in a biota. Setting of the dangerous concentration level is advisable to carry out through the "crucial center" within the tolerance range of the group of species, separate species, biochemical processes activity, etc.

In order to develop the arsenic negative impact standardization it is best to use the microbiological indicators of the soil conditions (the activity of the microorganisms which take part in the nitrogen conversion process) and the fitotests (red radishes with a white tip, garden cress). According to the experimental organisms reaction the dangerous concentration of the arsenic in the soil is one that exceeds $5 \mathrm{mg} / \mathrm{kg}$.

\section{ACKNOWLEDGEMENTS}

We greatly acknowledge the support of the Institute of Agroecology of the Ukrainian Academy of Agrarian Sciences, Kiev.

Received 9 July 2015 Accepted 7 December 2015

\section{REFERENCES}

1. Anoduad C., Okenwa L., Okieimen F., Tyowua A. T., Uwumarongie-Ilori E. 2009. Metal immobilization in CCA contaminated soil using laterite and termite mound soil. Evaluation by chemical fractionation. Nigerian Journal of Applied Science. Vol. 27. P. 77-87.

2. Bolan N., Ko B., Anderson C., Vogeler I. 2008. Solute interactions in soils in relation to bioavailability and remediation of the environment. Proceedings of the 5th International Symposium on Interactions of Soil Minerals with Organic Components and Microorganisms. Pucón, Chile.

3. Cechmankova J., Vacha R., Skala J., Havelkova M. 2011. Heavy metals phytoextraction from heavily and moderately contaminated soil by field crops grown in monoculture and crop rotation. Soil and Water Research. Vol. 6. P. 120-130.

4. Hashimoto Y., Matsufuru H., Takaoka M., Tanida H., Sato T. 2009. Impacts of chemical amendment and plant growth on lead speciation and enzyme activities in a shooting range soil: an X-ray absorption fine structure investigation. Journal of Environmental Quality. Vol. 38(4). P. 1420-1428.

5. Jigau G., Motelica M., Lesanu M., Tofan E., Georgescu L., Iticescu C., Rogut V., Nedealcov S. 2014. 
Heavy metals in the anthropogenic cycle of elements. In: Soil as World Heritage. P. 61-68.

6. Kabata-Pendias A. 2001. Trace Elements in Soil and Plants. Roca Raton: CRC Press.

7. Makarenko N., Bondar V. 2013. Technology of crops cultivation: environmental standardization by the degree of impact over agro-ecosystem's condition. Annals of Agrarian Science. Vol. 3. P. 56-61.

8. Mukherjee A., Sengupta M. K., Hossain M. A. 2006. Arsenic contamination in groundwater: A global perspective with emphasis on the Asian scenario. Journal of Health Population and Nutrition. Vol. 24(2). P. 142-163.

9. Sherene T. 2010. Mobility and transport of heavy metals in polluted soil environment. Biological Forum - An International Journal. Vol. 2. P. 112-121.

10. Wang L., Luo L., Ma Y., Wei D., Hua L. 2009. In situ immobilization remediation of heavy metalscontaminated soils: a review. Chinese Journal of Applied Ecology. Vol. 20(5). P. 1214-1222.

\section{Natalija Makarenko, Valerija Bondar \\ EKOTOKSIKOLOGINIS ARSENO VERTINIMAS DIRVOŽEMIUOSE NAUDOJANT KVIEČIŲ BIOTESTĄ}

Santrauka

Straipsnyje pristatomi dozès-atsako koreliacinès analizės pagal biotos pokyčius rezultatai. Parodyta „esminio centro“ (rūšies, kuri reglamentuoja cheminès medžiagos poveikio lygį) cheminių medžiagų poveikis ekosistemoms, t. y. ekotoksiškumo standartams. Vertinant arseno neigiamą poveikị aplinkai būtų racionalu taikyti dirvožemio mikrobiologinius rodiklius ir biotestus. Pagal jautriausių biologinių testų (aktyvusis nitrifikavimas; pipirinès, ridikèlio daigumas) rezultatus nustatyta, kad didesne kaip $5 \mathrm{mg} / \mathrm{kg}$ arseno koncentracija yra pavojinga gruntinio vandens sistemoms.

Raktažodžiai: arsenas, biologiniai tyrimai, ekotoksikologinis standartizavimas, dirvožemis 